\title{
Magnesium versus poly-L-lactic acid bioresorbable scaffolds: in vivo optical coherence tomography comparison of mechanical performance
}

\section{Andamiajes bioresorbibles de magnesio versus poliméricos: comparación in vivo de su comportamiento mecánico por OCT}

\author{
Rosa A. Abellás-Sequeiros ${ }^{1,2}$, Raymundo Ocaranza-Sanchez ${ }^{2 *}$, Carlos Galvaõ-Braga ${ }^{3}$, Jorge Marques ${ }^{3}$ y \\ Carlos Gonzalez-Juanatey² \\ ${ }^{1}$ Programa de Doctorado de la Universidad Santiago de Compostela, Santiago de Compostela; ${ }^{2}$ Unidad de Cardiología Intervencionista, Hospital \\ Universitario Lucus Augusti, Lugo, Spain; ${ }^{3}$ Unidad de Cardiología Intervencionista, Hospital de Braga, Braga, Portugal
}

\begin{abstract}
Background: Different mechanical properties have been suggested for metallic bioresorbable vascular scaffolds (BVS) in comparison to polymeric BVS. We aim to evaluate the acute mechanical performance of Magmaris ${ }^{\circledR}$ scaffold in comparison to Absorb $^{\circledR}$. Materials and Methods: Two groups of 10 coronary lesions treated with Magmaris ${ }^{\circledR}$ and Absorb ${ }^{\circledR} 1.1$ (20584 vs. 21016 struts) were compared. In all cases, optical coherence tomographic (OCT) images were acquired after scaffold deployment. Baseline clinical, angiographic, and procedural characteristics were compared, including OCT evaluations. Results: No baseline clinical or angiographic significant differences were found between groups. The most common indication for revascularization was effort angina (60\% vs. $70 \% \mathrm{p}=0.45)$ with no ST-elevation myocardial infarction (MI) cases. Main target artery was left anterior descending, with a mean vessel diameter of $3.46 \pm 0.23$ in Absorb ${ }^{\circledast}$ and $3.52 \pm 0.19 \mathrm{~mm}$ in Magmaris ${ }^{\circledR}$ groups $(p=0.56)$. All cases underwent pre- and post-dilatation with a procedural success rate of $100 \%$. OCT analyses showed larger scaffold and vessel diameters in Magmaris ${ }^{\circledR}$ group: $3.11 \pm 0.38 \mathrm{~mm}$ versus $3.07 \pm 0.36 \mathrm{~mm}, p=0.03$ and $4.12 \pm$ $0.51 \mathrm{~mm}$ versus $4.04 \pm 0.46 \mathrm{~mm}, p=0.04$. Despite the application of slightly higher postdilatation pressures to Magmaris ${ }^{\circledR}$ devices (18.01 \pm 2.15 vs. $17.20 \pm 3.80 \mathrm{~atm}, p=0.05$ ), significantly lower percentages of disrupted and malapposed struts were identified within Magmaris ${ }^{\circledast}$ scaffolds $(0.15 \%$ vs. $0.27 \%, p=0.03$ and $1.06 \%$ vs. $1.46 \% p=0.01)$. No cardiac death, target vessel-related $\mathrm{MI}$, or clinically driven target lesion revascularization was reported in a 30-day follow-up. Conclusion: Mechanical properties of Magmaris ${ }^{\circledast}$ scaffold allow achieving larger vessel and scaffold diameters in a safe manner, with lower rates of malapposition and scaffold disruption.
\end{abstract}

Key words: Bioresorbable scaffolds. Optical coherence tomography. Percutaneous coronary intervention. Magnesium scaffold.

\section{Resumen}

Introducción: Se ha sugerido la presencia de un distinto comportamiento mecánico entre los dos grupos principales de dispositivos bioresorbibles: metálicos y poliméricos. En este estudio evaluamos el comportamiento mecánico agudo del 
andamiaje bioresorbible metálico Magmaris ${ }^{\circledR}$ frente al del polimérico Absorb ${ }^{\circledR}$. Métodos: Se compararon dos grupos de 10 lesiones coronarias tratadas con Magmaris ${ }^{\circledR}$ y Absorb ${ }^{\circledR} 1.1$ (20584 vs. 21016 struts). En todos los casos se realizó estudio postimplante del dispositivo mediante tomografia de coherencia óptica (OCT). Se compararon las características basales clínicas y angiográficas, así como aspectos del procedimiento (incluídos los estudios de OCT) entre ambos grupos. Resultados: No se encontraron diferencias clínicas o angiográficas estadísticamente significativas entre ambos grupos. La indicación más frecuente de revascularización coronaria fué la presencia de angina de esfuerzo (60\% vs. $70 \% p=0.45)$, sin incluirse casos de IAMCEST. La arteria descendente anterior fué el principal vaso diana, con un diámetro medio de $3.46 \pm$ $0.23 \mathrm{~mm}$ en el grupo de Absorb ${ }^{\circledR}$ y de $3.52 \pm 0.19 \mathrm{~mm}$ en el grupo de Magmaris $^{\circledR}(p=0.56)$. En todos los casos se realizó pre y postdilatación, con una tasa de éxito del procedimiento del 100\%. Los estudios mediante OCT demostraron un mayor diámetro de stent y del vaso en el grupo de Magmaris $^{\circledR}: 3.11 \pm 0.38 \mathrm{~mm}$ versus $3.07 \pm 0.36 \mathrm{~mm}, p=0.03$ y $4.12 \pm 0.51 \mathrm{~mm}$ versus $4.04 \pm 0.46 \mathrm{~mm}, p=0.04$. A pesar de someter a los dispositivos Magmaris ${ }^{\circledR}$ a presiones de postdilatación ligeramente superiores (18.01 $\pm 2.15 \mathrm{vs}$. $17.20 \pm 3.80 \mathrm{~atm}, p=0.05)$, se identificó un menor porcentaje estadísticamente significativo de struts rotos o malapuestos en dicho grupo ( $0.15 \%$ vs. $0.27 \%, p=0.03$ y $1.06 \%$ vs. $1.46 \% p=0.01)$. En un seguimiento a 30 días no se registraron eventos mayores: muerte cardíaca, IM relacionado con vaso diana o TLR. Conclusión: Las propiedades mecánicas del scaffold metálico bioresorbible Magmaris ${ }^{\circledR}$ permiten alcanzar mayores diámetros de stent y vaso de forma segura tras su implante, con una baja tasa de malaposición y disrupción.

Palabras clave: Andamiajes bioresorbibles. OCT. PCI. Scaffold de magnesio.

\section{Introduction and objective}

Second-generation metallic drug-eluting stents (DESs) have become the first-line devices in percutaneous coronary intervention $(\mathrm{PCl})$ thanks to lower rates of target lesion revascularization (TLR), stent thrombosis (ST), and major adverse cardiac events (MACE) when compared to simple angioplasty and bare metal stents $^{1}$. Nevertheless, permanent caging of the vessel represents their main drawback. Bioresorbable vascular scaffolds (BVSs) appeared more than 10 years ago to avoid this problem. The first approved BVS was the Absorb ${ }^{\circledR}$ bioresorbable scaffolds (BRS) (Abbot Vascular, Santa Clara, California, USA) with an expected time to backbone resorption between 2 and 3 years due to PPLA hydrolysis ${ }^{2}$. To reduce this resorption process, Magmaris ${ }^{\circledR}$ scaffold (Biotronik AG, Bulach, Switzerland) was designed as the first non-polymeric scaffold, with a magnesium alloy backbone that can be completely degraded by $9-12$ months after $\mathrm{PCl}^{3}$. Optimal expansion and apposition, with no significant scaffold disruption, have been demonstrated for Absorb ${ }^{\circledR}$ BVS immediately after $\mathrm{PCl}^{4}$; however, there is few evidence regarding Magmaris ${ }^{\circledR}$ acute performance after $\mathrm{PCl}$.

\section{Materials and methods}

\section{Study design and patient population}

This study wants to evaluate the mechanical properties and performance of Magmaris ${ }^{\circledR}$ scaffold at baseline (immediately after $\mathrm{PCl}$ ) in comparison to the most studied BVS: the Absorb $1.1^{\circledR}$ (Abbot Vascular, Santa Clara, California, USA). Within the global pool of patients admitted to $\mathrm{PCl}$ in our cath lab between November 2016 and October 2017, we looked for those who could benefit the most from metallic BRS 5 . According to this, 10 coronary lesions were treated with Magmaris ${ }^{\circledR}$ device in 10 different patients. Lesions considered as suitable for Magmaris ${ }^{\circledR}$ deployment included: de novo coronary lesions with a diameter between 2.5 and $3.5 \mathrm{~mm}$ and with none/ mild calcification. Bifurcation lesions were also admitted, and there were no restrictions regarding $\mathrm{PCl}$ indication: stable angina and acute coronary syndrome were admitted. Left main disease (left main coronary artery disease [LMCD]) and ostial lesions were excluded, as well as chronic total occlusions or in-stent restenosis.

The clinical exclusion criteria included age $>75$ years old, history or high risk of bleeding, heparin or antiplatelet treatments intolerance, and expected survival $<1$ year.

On the other hand, 10 patients with 10 coronary lesions who had undergone $\mathrm{PCl}$ with at least one Absorb 1.1 ${ }^{\circledR}$ BVS represented the control group. They were selected in a retrospective, blinded, non-randomized way from the total cohort of patients treated with Absorb $^{\circledR}$ who had undergone intracoronary optical coherence tomography (OCT) evaluation at baseline. All indications for $\mathrm{PCl}$ had been admitted. The only angiographic exclusion criteria for this group had been: LMCD and lesions with diameters $<2.5 \mathrm{~mm}$ or $>4 \mathrm{~mm}$. The aforementioned clinical exclusion criteria also applied to this group with the only exception of age.

Informed written consent was obtained in all cases. 


\section{Study devices}

Ten coronary lesions were treated with Magmaris ${ }^{\circledR}$ scaffold and 10 lesions with Absorb 1.1 ${ }^{\circledR}$ BVS. Even though Absorb ${ }^{\circledR}$ and Magmaris ${ }^{\circledR}$ are both of them BRS, important differences between their conformation and behavior must be highlighted. Magmaris ${ }^{\circledR}$ scaffold is the only available metallic BRS with CE approval. Its magnesium alloy backbone is completely coated by a bioresorbable polymeric layer of poly-L-lactic acid (PLLA) from which sirolimus antiproliferative drug is released $^{6}$. The strut thickness is $150 \mu \mathrm{m}^{5}$. On the contrary, Absorb ${ }^{\circledR}$ BVS is an everolimus-eluting polymeric BRS, with a PLLA backbone covered by a poy-D-lactic acid coating ${ }^{2}$. Absorb ${ }^{\circledR}$ strut thickness accounts to 156 $\mu \mathrm{m}^{2}$. Different mechanical properties have been described for these devices as, for example, higher tensile strength and elongation-to-break for Magmaris ${ }^{\circledR 5}$. Nevertheless, the main difference between them is the expected time to completely scaffold resorption: 9-12 months for Magmaris ${ }^{\circledR 3,6}$ and 2-3 years for Absorb $^{\circledR}$ BVS $^{2}$.

\section{Procedure and OCT analyses}

In our study, predilatation was mandatory for both groups. Semi-compliant balloons were used in a 1:1 balloon/artery relationship to warrant an optimal preparation of the lesion. Between all the different available diameters and lengths for each device, the operator decided the most appropriate size in each case according to visual and OCT assessment. Scaffold overlapping was allowed if necessary to warrant a completely coverage of the lesion. Per protocol, high-pressure postdilatation was mandatory after scaffold deployment in both Absorb $^{\circledR}$ and Magmaris ${ }^{\circledR}$ groups. Non-compliant balloons were used in 1:1 balloon/scaffold relationship, with a minimum inflation pressure of 16 atmospheres (atm).

OCT intracoronary analyses were performed with the Lunawave Coronary console ${ }^{\circledR}$ and the Fastview Catheter $^{\circledR}$ (Terumo Corp., Tokyo, Japan). In all cases, OCT evaluation was done after lesion predilatation and both after scaffold deployment and postdilatation to warrant: (a) the best evaluation of the lesion, (b) appropriate size of the device, and (c) optimal scaffold expansion and apposition. Images acquisition technique has been previously described ${ }^{4}$.

Quantitative OCT analyses were done with the offline software provided by Terumo ${ }^{\circledR}$ (Terumo Corp., Tokyo, Japan). In both groups, we measured frame by frame all the scaffold segment of the vessel. Lumen, scaffold, and vessel diameters were measured, and malapposed and disrupted struts were also identified. Definitions and analysis methods have been previously published, and they were applied in both the Absorb ${ }^{\circledR}$ and Magmaris ${ }^{\circledR}$ groups $^{4,6}$.

All procedures were performed from a radial approach and under unfractionated heparin treatment. Dual antiplatelet therapy with aspirin and a P2Y12 inhibitor was recommended according to current guidelines for a minimum of 12 months?

\section{Study endpoints}

\section{Primary endpoint}

Evaluation of acute effectiveness and safety of two different BVSs (Absorb $1.1^{\circledR}$ and Magmaris ${ }^{\circledR}$ ) regarding OCT postprocedure evaluation of lumen, scaffold, and vessel diameters, as well as percentage of struts disruption and malapposition.

\section{SECONDARY ENDPOINTS INCLUDE}

Procedural success rate (defined as the achievement of a residual stenosis $<20 \%$ in the absence of death, myocardial infarction [MI], or TLR during in-hospital stay), and MACE rate at 30-day follow-up (defined as the combination of cardiac death, target vessel-related $\mathrm{MI}$, and clinically driven TLR).

\section{Statistical analysis}

Continuous variables with a normal distribution are presented as mean and standard deviations, while categorical variables are presented as percentages. Unpaired t-test (in case of parametric distribution) or Mann-Whitney U-test (in case of non-parametric distribution) was used to compare continuous variables between groups. Chi-square test or Fisher's exact test was used to assess significance associations for categorical variables. A $p<0.05$ was considered statistically significant. Statistical analyses were performed using SPSS version 21.

\section{Results}

A total of 20 patients (20 lesions) were included in this study. Eighteen Absorb ${ }^{\circledR}$ scaffolds were deployed for the treatment of 10 lesions between June and October 2015, and 10 lesions received 17 Magmaris $^{\circledR}$ devices 
Table 1. Baseline patients characteristics

\begin{tabular}{|c|c|c|c|}
\hline & PLLA BVS group & Mg scaffold group & $p$ value \\
\hline & n: 10 (100\%) & n: 10 (100\%) & \\
\hline Age (years) & $56.79 \pm 11.38$ & $65.35 \pm 9.75$ & 0.45 \\
\hline $\begin{array}{l}\text { Women } \\
\text { Current smokers } \\
\text { Ex-smokers } \\
\text { Non-smokers }\end{array}$ & $\begin{array}{l}2(20) \\
4(40) \\
3(30) \\
3(30)\end{array}$ & $\begin{array}{l}3(30) \\
5(50) \\
3(30) \\
2(20)\end{array}$ & $\begin{array}{l}0.38 \\
0.37 \\
\text { NA } \\
0.38\end{array}$ \\
\hline Arterial hypertension & $6(60)$ & $7(70)$ & 0.45 \\
\hline $\begin{array}{l}\text { Dislypemia } \\
\text { DM on AOD } \\
\text { DM on insulin }\end{array}$ & $\begin{array}{l}9(90) \\
3(30) \\
1(10)\end{array}$ & $\begin{array}{c}7(70) \\
4(40) \\
0\end{array}$ & $\begin{array}{c}>0.45 \\
\emptyset 0.45 \\
0.09\end{array}$ \\
\hline $\begin{array}{l}\text { Body mass index } \\
<25 \mathrm{~kg} / \mathrm{m}^{2} \\
25-29.9 \mathrm{~kg} / \mathrm{m}^{2} \\
\geq 30 \mathrm{~kg} / \mathrm{m}^{2}\end{array}$ & $\begin{array}{l}0 \\
5(50) \\
5(50)\end{array}$ & $\begin{array}{c}0 \\
4(40) \\
6(60)\end{array}$ & $\begin{array}{l}\text { NA } \\
0.37 \\
0.25\end{array}$ \\
\hline Previous stroke & 0 & 0 & NA \\
\hline Peripheral artery disease & $2(20)$ & $2(20)$ & NA \\
\hline Atrial fibrillation & 0 & 0 & NA \\
\hline Previous coronary artery disease & $1(10)$ & $1(10)$ & NA \\
\hline Previous target vessel revascularization & 0 & 0 & NA \\
\hline $\begin{array}{l}\text { Current indication for } \mathrm{PCI} \\
\text { Effort angina } \\
\text { ACS without ST segment elevation } \\
\text { STEMI }\end{array}$ & $\begin{array}{c}7(70) \\
3(30) \\
0\end{array}$ & $\begin{array}{c}6(60) \\
4(40) \\
0\end{array}$ & $\begin{array}{l}>0.45 \\
0.45 \\
\text { NA }\end{array}$ \\
\hline HbA1c (\%) & $6.05 \pm 0.99$ & $6.99 \pm 0.78$ & 0.28 \\
\hline Haemoglobine $\mathrm{g} / \mathrm{dL}$ & $14.72 \pm 0.82$ & $14.43 \pm 0.35$ & 0.54 \\
\hline Platelets $\times 10^{3} / \mu \mathrm{L}$ & $270.07 \pm 93.4$ & $253.52 \pm 85.30$ & 0.21 \\
\hline Creatinine $\mathrm{mg} / \mathrm{dl}$ & $0.77 \pm 0.16$ & $0.81 \pm 0.21$ & 0.24 \\
\hline Mean eGFR mL/min/1.73 m² & $112.31 \pm 37.48$ & $109.91 \pm 41.3$ & 0.17 \\
\hline Minimun eGFR & 80.78 & 79.3 & 0.43 \\
\hline
\end{tabular}

Values are $\mathrm{n}(\%)$ or mean \pm standard deviation; *NA: not applicable. ACS: acute coronary syndrome; AOD: antidiabetic oral drugs; DM: Diabetes Mellitus; ${ }^{\times}$eGFR: estimated glomerular filtration rate; STEMI: ST-elevation myocardial infarction; HbA1c: hemoglobin A1C; BVS: bioresorbable vascular scaffolds; PLLA: poly-L-lactic acid.

between November 2016 and October 2017. Baseline clinical characteristics were well balanced between groups (Table 1). Most patients were men, with age ranged between 55 and 65 years and with a diagnosis of hypertension ( $60 \%$ vs. $70 \%$, non-significant [NS]) and dyslipidemia ( $90 \%$ vs. $70 \%$ NS). No patients suffered from anemia or chronic kidney disease.

The most common indication for $\mathrm{PCl}$ was effort angina in both groups ( $70 \%$ vs. $60 \%$ NS) with no ST-elevation $\mathrm{Ml}$ cases included. Main target vessel was left anterior descendent artery in both $\mathrm{Absorb}^{\circledR}(70 \%)$ and Magmaris $^{\circledR}$ group $(80 \%)$, with a mean vessel diameter of $3.46 \pm 0.23$ and $3.52 \pm 0.19 \mathrm{~mm}, p=0.56$, respectively. According to the American Heart Association classification, the most lesions were identified as moderate/ high-risk lesions: $40 \%$ versus $60 \%, p=0.37$ were type $B$ and $40 \%$ versus $30 \%, p=0.45$ were type $C$ lesions in Absorb ${ }^{\circledR}$ and Magmaris ${ }^{\circledR}$ group, respectively. No statistically significant differences between groups were identified regarding to angiographic and procedural characteristics (Table 2) unless slightly higher postdilatation pressures for Magmaris ${ }^{\circledR}$ devices (18.01 \pm 2.15 vs. $17.20 \pm 3.80 \mathrm{~atm}, p=0.05$ ). Procedural success rate was $100 \%$. Postprocedural OCT findings are 
Table 2. Angiographic lesion characteristics and procedural aspects

\begin{tabular}{|c|c|c|c|}
\hline & PLLA BVS group & Mg scaffold group & p value \\
\hline Angiographic lesion characteristic (\%) & $10(100)$ & $10(100)$ & \\
\hline $\begin{array}{l}\text { Treated artery } \\
\text { Left anterior descendent artery } \\
\text { Right coronary artery }\end{array}$ & $\begin{array}{l}7(70) \\
3(30)\end{array}$ & $\begin{array}{l}8(80) \\
2(20)\end{array}$ & $\begin{array}{l}0.39 \\
0.38\end{array}$ \\
\hline $\begin{array}{l}\text { AHA lesion classification } \\
\text { A } \\
\text { B } \\
\text { C }\end{array}$ & $\begin{array}{l}2(20) \\
4(40) \\
4(40)\end{array}$ & $\begin{array}{l}1(10) \\
6(60) \\
3(30)\end{array}$ & $\begin{array}{l}0.39 \\
0.37 \\
0.45\end{array}$ \\
\hline Bifurcations & $1(10)$ & $1(10)$ & NA \\
\hline Chronic total occlusions & 0 & 0 & NA \\
\hline Thrombus & $2(20)$ & $1(10)$ & 0.39 \\
\hline Mean vessel diameter mm & $3.46 \pm 0.23$ & $3.52 \pm 0.19$ & 0.56 \\
\hline $\begin{array}{l}\text { Procedural aspects } \\
\text { Predilatation } \\
\text { Mean predilatation balloon diameter mm } \\
\text { Mean predilatation balloon length mm } \\
\text { Mean predilation balloon pressure atm } \\
\text { Mean number of BVS deployed per lesion } \\
\text { Mean BVS diameter mm } \\
\text { Mean BVS length mm } \\
\text { Mean total length scaffold per lesion mm } \\
\text { Mean pressure used in BVS deployment atm } \\
\text { Postdilatation } \\
\text { Mean postdilatation balloons diameter mm } \\
\text { Mean postdilatation balloons length mm } \\
\text { Mean postdilatation balloon pressure atm } \\
\text { Maximum postdilatation balloon pressure atm } \\
\text { Postdilatation balloon/scaffold diameter ratio }\end{array}$ & $\begin{array}{c}10(100) \\
3.2 \pm 0.36 \\
19.2 \pm 4.37 \\
12.4 \pm 3.04 \\
1.79 \\
3.22 \pm 0.32 \\
22.5 \pm 5.34 \\
35.21 \pm 19.25 \\
14.08 \pm 2.73 \\
10(100) \\
3.5 \pm 0.32 \\
13.09 \pm 3.55 \\
17.20 \pm 3.80 \\
20.00 \pm 3.80 \\
1.01\end{array}$ & $\begin{array}{c}10(100) \\
3.39 \pm 0.21 \\
19.4 \pm 3.2 \\
13.2 \pm 2.9 \\
1.63 \\
3.27 \pm 0.28 \\
21.7 \pm 6.16 \\
32.19 \pm 15.38 \\
14.98 \pm 3.10 \\
10(100) \\
3.49 \pm 0.39 \\
13.78 \pm 2.25 \\
18.01 \pm 2.15 \\
21.00 \pm 3.75 \\
1.02\end{array}$ & $\begin{array}{l}\text { NA } \\
0.52 \\
0.67 \\
0.49 \\
0.23 \\
0.21 \\
0.41 \\
0.09 \\
0.21 \\
\text { NA } \\
0.23 \\
0.19 \\
0.05^{*} \\
0.04^{*} \\
0.19\end{array}$ \\
\hline $\begin{array}{l}\text { Pre-PCI TIMI flow } \\
0 / / \\
\text { II } \\
\text { III }\end{array}$ & $\begin{array}{c}0 \\
3(30) \\
7(70)\end{array}$ & $\begin{array}{c}0 \\
1(10) \\
9(90)\end{array}$ & $\begin{array}{c}\mathrm{NA} \\
0.44 \\
>0.45\end{array}$ \\
\hline Post-PCI TIMI III flow & $10(100)$ & $10(100)$ & NA \\
\hline
\end{tabular}

Values are $\mathrm{n}(\%)$ or mean \pm standard deviation.

*NA: not applicable.

BVS: bioresorbable vascular scaffold; PCl: percutaneous coronary intervention; PLLA: poly-L-lactic acid; AHA: American Heart Association.

presented in Table 3. We analyzed 21,016 PLLA struts and 20,584 magnesium struts in each group. Both mean scaffold and vessel diameters were significantly larger in Magmaris ${ }^{\circledR}$ group: $3.11 \pm 0.38$ versus $3.07 \pm 0.36 \mathrm{~mm}$, $p=0.03$ and $4.12 \pm 0.51$ versus $4.04 \pm 0.46 \mathrm{~mm}, p=0.04$; even in the presence of higher plaque burden (mean plaque area was $6.17 \pm 1.79 \mathrm{~mm}^{2}$ in Magmaris ${ }^{\circledR}$ group versus $6.07 \pm 1.28 \mathrm{~mm}^{2}$ in Absorb $^{\circledR}$ group, $p=0.02$ ). Low rates of malapposition and acute scaffold disruption were demonstrated for both devices after high pressure postdilatation; nevertheless, we identified significantly lower percentages of malapposed $(1.06 \%$ vs. $1.46 \%$, $p=0.01)$ and disrupted struts $(0.15 \%$ vs. $0.27 \%$, $p=0.03$ ) in Magmaris ${ }^{\circledR}$ group. All patients completed 30-day follow-up with no cardiac death, target vessel-related MI, or clinically-driven TLR reported.

\section{Discussion}

In this study, we evaluated postprocedural performance of Magmaris ${ }^{\circledR}$ scaffold in comparison to the most studied to the date BVS: the Absorb $1.1^{\circledR}$ (Abbot Vascular, Santa Clara, California, USA). The chief findings are as follows: (a) there is no "class effect" regarding acute device performance between metallic and polymeric BRS, (b) higher scaffold and vessel diameters can be achieved with Magmaris ${ }^{\circledR}$ device in comparison to same size Absorb ${ }^{\circledR}$ BVS, (c) significantly higher percentage of 
Table 3: Baseline optical coherence tomography findings. Lesion-level and strut-level analyses

\begin{tabular}{|c|c|c|c|}
\hline & PLLA BVS & Mg scaffold & p value \\
\hline & 18 devices & 17 devices & \\
\hline $\begin{array}{l}\text { Lesion-level analyses } \\
\text { Mean lumen diameter } \mathrm{mm} \\
\text { Minimal lumen diameter } \mathrm{mm} \\
\text { Maximal lumen diameter } \mathrm{mm} \\
\text { Mean vessel diameter } \mathrm{mm} \\
\text { Minimal vessel diameter } \mathrm{mm} \\
\text { Maximal vessel diameter } \mathrm{mm} \\
\text { Mean scaffold diameter } \mathrm{mm} \\
\text { Minimal scaffold diameter } \mathrm{mm} \\
\text { Maximal scaffold diameter } \mathrm{mm} \\
\text { Mean plaque area } \mathrm{mm}^{2} \\
\text { Mean eccentricity index }\end{array}$ & $\begin{array}{l}2.91 \pm 0.38 \\
2.70 \pm 0.73 \\
3.15 \pm 0.41 \\
4.04 \pm 0.46 \\
3.87 \pm 0.42 \\
4.18 \pm 0.47 \\
3.07 \pm 0.36 \\
2.86 \pm 0.42 \\
3.30 \pm 0.36 \\
6.07 \pm 1.28 \\
0.13 \pm 0.05\end{array}$ & $\begin{array}{l}2.99 \pm 0.91 \\
2.73 \pm 0.76 \\
3.22 \pm 0.38 \\
4.12 \pm 0.51 \\
3.91 \pm 0.48 \\
4.23 \pm 0.60 \\
3.11 \pm 0.38 \\
2.90 \pm 0.70 \\
3.38 \pm 0.46 \\
6.17 \pm 1.79 \\
0.09 \pm 0.01\end{array}$ & $\begin{array}{l}0.08 \\
0.07 \\
0.06 \\
0.04 \\
0.05 \\
0.03 \\
0.03 \\
0.02 \\
0.03 \\
0.02 \\
0.02\end{array}$ \\
\hline $\begin{array}{l}\text { Strut-level analyses } \\
\text { Number of struts analyzed } \\
\% \text { of malapposed struts } \\
\text { Total number of malapposed struts } \\
\% \text { of disrupted struts } \\
\text { Total number of disrupted struts }\end{array}$ & $\begin{array}{c}21,016 \\
1.46 \\
308 \\
0.27 \\
58\end{array}$ & $\begin{array}{c}20,584 \\
1.06 \\
219 \\
0.15 \\
31\end{array}$ & $\begin{array}{l}0.29 \\
0.01 \\
\\
0.03\end{array}$ \\
\hline
\end{tabular}

Values are $\mathrm{n}(\%)$ or mean \pm standard deviation.

PLLA: poly-L-lactic acid; BVS: bioresorbable vascular scaffold.

elongation-to-break for Magmaris ${ }^{\circledR}$ device allows the operator to achieve higher scaffold and vessel diameters in a safe manner, with lower rates of acute scaffold disruption, and (d) for the same reason, high-pressure postdilatation has been demonstrated to be safe and useful as it reduces malapposition rates.

BVS "class effect" has been suggested due to their common resorbable nature and structural features, such as wide struts thickness (150 $\mu \mathrm{m}$ approximately) $)^{2,5,8}$. Absorb ${ }^{\circledR}$ and Desolve ${ }^{\circledR}$ are the polymeric scaffolds meanwhile Magmaris ${ }^{\circledR}$ is the only metallic BRS. Mattesini et al. ${ }^{9}$ demonstrated comparable results in terms of mean lumen and scaffold area when analyzing postdeployment OCT evaluations for both polymeric devices, so similar acute mechanical properties have been suggested for both Absorb $^{\circledR}$ and Desolve ${ }^{\circledR}$. However, do these results also apply to metallic BRS? A time-dependent recoil phenomenon as well as higher rates of acute recoil has been demonstrated for polymeric BVS when compared to Magmaris ${ }^{\circledR}$ in preclinical studies $^{10}$. We report the first in vivo comparison of acute mechanical performance between Magmaris ${ }^{\circledR}$ and Absorb ${ }^{\circledR}$ devices. Significantly, larger vessel and scaffold diameters were demonstrated in Magmaris ${ }^{\circledR}$ group when comparing to a well-balanced cohort of patients treated with Absorb $^{\circledR}(4.12 \pm 0.51$ vs. $4.04 \pm 0.46 \mathrm{~mm}, p=0.04$ and $3.11 \pm 0.38$ vs. 3.07 $\pm 0.36 \mathrm{~mm}, p=0.03$, respectively). As there were significant differences neither in lesion characteristics nor in procedural aspects between groups, these results suggest higher expansion and radial force for Magmaris ${ }^{\circledR}$. Furthermore, lower eccentricity index $(0.09 \pm$ 0.01 vs. $0.13 \pm 0.05, p=0.02$ ) supports the idea of a better geometrical adaptation to the vessel wall for magnesium BVS, which could be explained thanks to its lower bending stiffness and higher flexibility ${ }^{10}$.

In addition to this, Magmaris ${ }^{\circledR}$ greater percentage of elongation-at-break had been hypothesized attending to mechanical properties of magnesium alloy ${ }^{11}$. Nevertheless, no clinical evidence was available. We evaluated for the first time in vivo acute scaffold disruption of Magmaris ${ }^{\circledR}$ device by OCT intracoronary imaging (Fig. 1). The percentage of disrupted struts in Magmaris $^{\circledR}$ group was minimal and significantly lower than in the Absorb $^{\circledR}$ group ( $0.15 \%$ vs. $\left.0.27 \%, p=0.03\right)$. These results confirm metallic BRS higher resistance to rupture, even when postdilatated at higher pressure levels $(18.01 \pm 2.15$ vs. $17.20 \pm 3.80 \mathrm{~atm}, p=0.05)$.

Main concern about polymeric scaffolds comes from their original slightly higher rates of ST when comparing to second-generation DES ${ }^{12,13}$. Nevertheless, the application of the "PSP" strategy (including high-pressure postdilatation) has demonstrated a significant reduction in ST and MACE rates after BVS scaffolding with the Absorb ${ }^{\circledR}$ device $^{14,15}$, with no higher rates of acute scaffold disruption ${ }^{4}$. In line with this, we decided to perform and evaluate high-pressure postdilatation "per protocol" in all lesions treated with Magmaris ${ }^{\circledR}$ in 


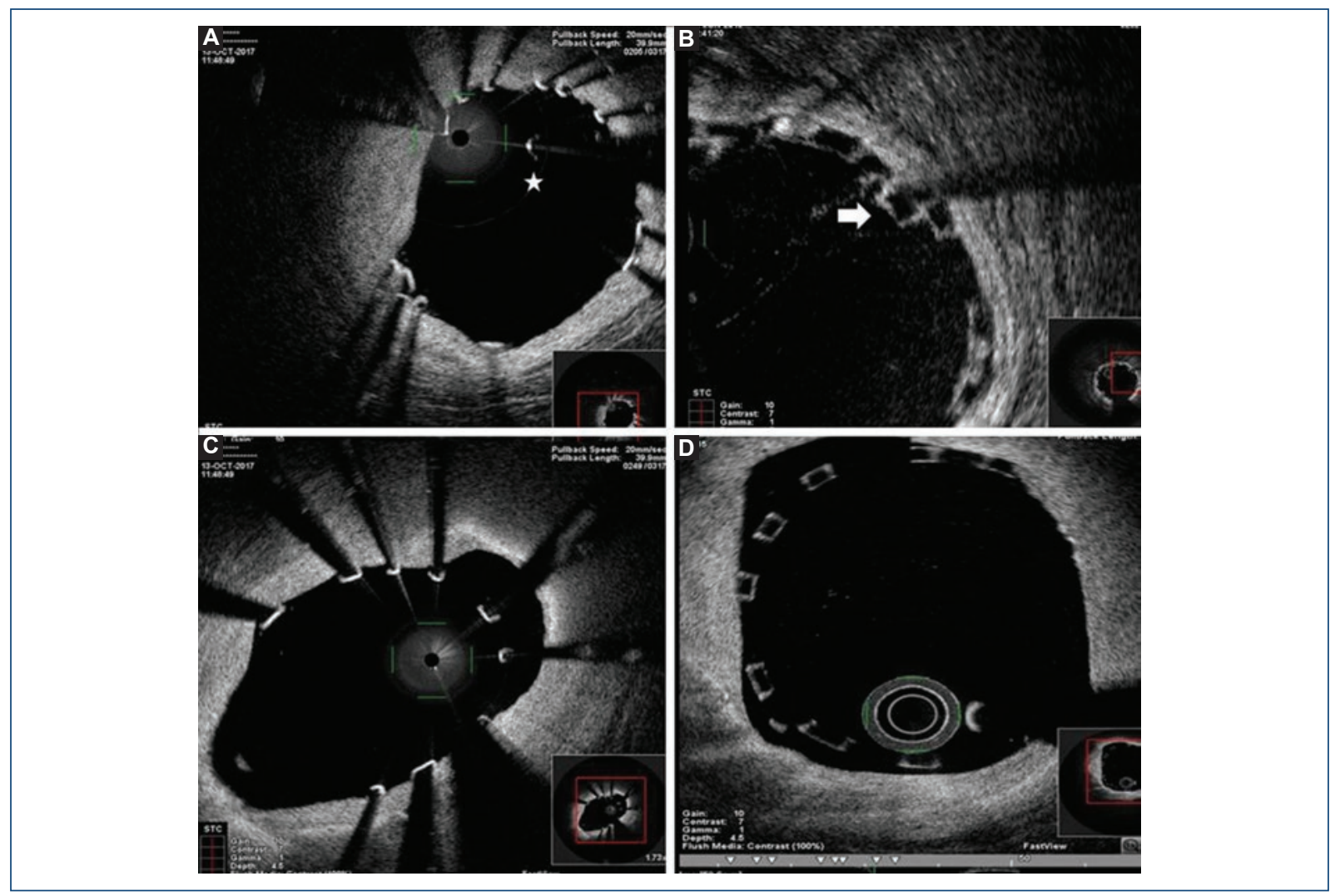

Figure 1. Optical coherence tomography (OCT) in vivo evaluation of Magmaris ${ }^{\circledR}$ and $A$ bsorb ${ }^{\circledR}$ scaffolds disruption and malapposition. 1A and 1B: show different OCT intracoronary images of disrupted struts: the star points to a magnesium isolated strut and the arrow a stacked polymeric disrupted strut. Meanwhile, images 1C and 1D show metallic (1C) and polymeric (1D) bioresorbable scaffolds malapposition.

our cath lab. We confirmed that a greater percentage of elongation-at-break allowed the operator to reduce Magmaris $^{\circledR}$ malapposition rates in a safe manner (1.06\% vs. $1.46 \%, p=0.01$ of malapposed struts in Magmaris $^{\circledR}$ and Absorb $^{\circledR}$ groups, respectively). Even though Magmaris ${ }^{\circledR}$ device has been suggested to have lower acute thrombogenicity ${ }^{16}$ with no reported cases of $S T^{6,17,18}$, it is well known that malapposition and infraexpansion significantly increase the risk of scaffold thrombosis and restenosis. According to this, we support the use of high-pressure postdilatation after magnesium-scaffold deployment to optimize angiographic and secondary clinical results, specially avoiding scaffold malapposition (Fig. 1).

In conclusion, this first comparative study between Absorb $^{\circledR}$ and Magmaris ${ }^{\circledR}$ devices supports the use of a "PSP strategy" for both scaffolds deployment. Optimal preparation of the lesion joined to appropriate sizing of the scaffold and high-pressure postdilatation reduces scaffold infraexpansion and malapposition, without acute security concerns. However, slight differences in acute mechanical performance between both devices have also been demonstrated, refusing a common "class effect" for all BVS.

\section{Limitations}

Main limitation of our study comes from the small number of patients included. However, we want to highlight that this study is the one which includes the highest number of struts analyzed for Magmaris ${ }^{\circledR}$ device after deployment (20584 struts vs. only 195.67 struts in Biosolve II trial $\left.{ }^{6}\right)$. Moreover, the date is the only study which compares Absorb ${ }^{\circledR}$ versus Magmaris ${ }^{\circledR}$ scaffolds. We are also aware of limitations derived from the non-randomized, observational nature of the study, as well as the possible bias generated by patients' selection. Nevertheless, we would like to emphasize patients/lesions included represent the target population for these devices. More evidence is needed to confirm our findings in a larger population, as well as to complete short-long-term clinical follow-up. 


\section{Conclusion}

Mechanical properties of Magmaris ${ }^{\circledR}$ scaffold allow the operator to achieve larger vessel and scaffold diameters in a safe manner, with lower rates of malapposition and scaffold disruption.

\section{Conflicts of interest}

The authors report no competing interests.

\section{Funding}

There are no grants for this study.

\section{Ethical disclosures}

Protection of human and animal subjects. The authors declare that no experiments were performed on humans or animals for this study.

Confidentiality of data. The authors declare that they have followed the protocols of their work center on the publication of patient data.

Right to privacy and informed consent. The authors declare that no patient data appear in this article.

\section{References}

1. Authors/Task Force members, Windecker S, Kolh P, Alfonso F, Collet JP, Cremer J, et al. 2014 ESC/EACTS guidelines on myocardial revascularization: the task force on myocardial revascularization of the European Society of Cardiology (ESC) and the European Association for Cardio-thoracic Surgery (EACTS) Developed with the special contribution of the European Association of Percutaneous Cardiovascular Interventions (EAPCI). Eur Heart J. 2014;35:2541-619.

2. Onuma $Y$, Serruys PW. Bioresorbable scaffold: the advent of a new era in percutaneous coronary and peripheral revascularization? Circulation. 2011;123:779-97.

3. Iqbal J, Onuma Y, Ormiston J, Abizaid A, Waksman R, Serruys P, et al. Bioresorbable scaffolds: rationale, current status, challenges, and future. Eur Heart J. 2014;35:765-76.

4. Abellas-Sequeiros RA, Ocaranza-Sanchez R, Galvão Braga C, Raposeiras-Roubin S, Lopez-Otero D, Cid-Alvarez B, et al. Assessment of effectiveness and security in high pressure postdilatation of bioresorbable vascular scaffolds during percutaneous coronary intervention. Study in a contemporary, non-selected cohort of Spanish patients. Int J Cardiol. 2016; 219:264-70.

5. Fajadet J, Haude M, Joner M, Koolen J, Lee M, Tölg R, et al. Magmaris preliminary recommendation upon commercial launch: a consensus from the expert panel on 14 April 2016. Eurolntervention. 2016;12:828-33.

6. Haude M, Ince H, Abizaid A, Toelg R, Lemos PA, von Birgelen C, et al Safety and performance of the second-generation drug-eluting absorbable metal scaffold in patients with de-novo coronary artery lesions (BIOSOLVE-II): 6 month results of a prospective, multicentre, non-randomised, first-in-man trial. Lancet. 2016;387:31-9.

7. Valgimigli M, Bueno H, Byrne RA, Collet JP, Costa F, Jeppsson A, et al. 2017 ESC focused update on dual antiplatelet therapy in coronary artery disease developed in collaboration with EACTS: the task force for dual antiplatelet therapy in coronary artery disease of the European Society of Cardiology (ESC) and of the European Association for Cardio-thoracic Surgery (EACTS). Eur Heart J. 2018;39:213-60.

8. Verheye S, Ormiston JA, Stewart J, Webster M, Sanidas E, Costa R, et al. A next-generation bioresorbable coronary scaffold system: from bench to first clinical evaluation: 6 and 12-month clinical and multimodality imaging results. JACC Cardiovasc Interv. 2014;7:89-99.

9. Mattesini A, Boeder N, Valente S, Löblich K, Dörr O, Secco GG, et al. Absorb vs. DESolve: an optical coherence tomography comparison of acute mechanical performances. Eurolntervention. 2016;12:e566-73.

10. Schmidt W, Behrens P, Brandt-Wunderlich C, Siewert S, Grabow N, Schmitz KP, et al. In vitro performance investigation of bioresorbable scaffolds standard tests for vascular stents and beyond. Cardiovasc Revasc Med. 2016;17:375-83.

11. Sotomi $Y$, Onuma $Y$, Collet C, Tenekecioglu E, Virmani R, Kleiman NS, et al. Bioresorbable scaffold: the emerging reality and future directions. Circ Res. 2017;120:1341-52.

12. Mahmoud AN, Barakat AF, Elgendy AY, Schneibel E, Mentias A, Abuzaid A, et al. Long-term efficacy and safety of everolimus-eluting bioresorbable vascular scaffolds versus everolimus-eluting metallic stents: a meta-analysis of randomized trials. Circ Cardiovasc Interv. 2017;10:e005286.

13. Montone RA, Niccoli G, De Marco F, Minelli S, D'Ascenzo F, Testa L, et al. Temporal trends in adverse events after everolimus-eluting bioresorbable vascular scaffold versus everolimus-eluting metallic stent implantation: a meta-analysis of randomized controlled trials. Circulation. 2017;135:2145-54.

14. Markovic S, Kugler C, Rottbauer W, Wöhrle J. Long-term clinical results of bioresorbable absorb scaffolds using the PSP-technique in patients with and without diabetes. J Interv Cardiol. 2017;30:325-30.

15. Ortega-Paz L, Capodanno D, Gori T, Nef H, Latib A, Caramanno G, et al. Predilation, sizing and post-dilation scoring in patients undergoing everolimus-eluting bioresorbable scaffold implantation for prediction of cardiac adverse events: development and internal validation of the PSP score. Eurolntervention. 2017;12:2110-7.

16. Waksman R, Lipinski MJ, Acampado E, Cheng Q, Adams L, Torii S, et al. Comparison of acute thrombogenicity for metallic and polymeric bioabsorbable scaffolds: magmaris versus absorb in a porcine arteriovenous shunt model. Circ Cardiovasc Interv. 2017;10:e004762.

17. Haude M, Ince H, Abizaid A, Toelg R, Lemos PA, von Birgelen $C$, et al. Sustained safety and performance of the second-generation drug-eluting absorbable metal scaffold in patients with de novo coronary lesions: 12-month clinical results and angiographic findings of the BIOSOLVE-II first-in-man trial. Eur Heart J. 2016;37:2701-9.

18. Haude M, Ince H, Kische S, Abizaid A, Tölg R, Alves Lemos P, et al. Sustained safety and clinical performance of a drug-eluting absorbable metal scaffold up to 24 months: pooled outcomes of BIOSOLVE-II and BIOSOLVE-III. Eurolntervention. 2017;13:432-9. 